IIUC STUDIES

ISSN 1813-7733

Vol.- 7, December 2010

(Published in December 2011) (p 117-130)

\title{
Internet Peculiarity and Territorial Traditionalism Converge on Cyberspace: A Study of Techno-legal Synchronization in the USA
}

\author{
Kazi Arshadul Hoque* \\ Mohammad Mahabubur Rahman ${ }^{* *}$
}

\begin{abstract}
Law is enacted and imposed by sovereign state authority. As the states are territorial in nature, the enforcement of law depends to a large extend on the ability to exercise physical control over the territory. Cyberspace and internet have no territorial-based boundaries and are almost entirely independent of physical location. In spite of inevitability of a distinct set of laws and legal principles to be adopted for cyber offences the traditional territorial law can supply element for cyber legal issues. The hi-tech pioneer American courts whether federal or provincial are very much inclined to decide the internet-cases on the basis of territorial concept by applying the principles of traditional territorial notions. This article concentrates on the study of the American cases as a representative type of hi-tech nations for searching the influences of traditional territorial concept on the settlement of internet-cases and the way for overcoming the problems came out of cyber peculiarity. This article will show how law together with internet has created a new environment in legal arena; and how the USA as high-tech nation relying upon previous territorial experience is making new pathway for the jurists, courts and all others. This article is based on keen observation and intensive analysis of American practice.
\end{abstract}

\section{Introduction}

Law is enacted or adopted more or less by a legislature in modern perspective. It is applied and developed by the court. Both legislature

* Lecturer, Department of Law, IIUC.

** Metropolitan Magistrate \& Special Metropolitan Magistrate, Chittagong City Corporation. 
and court are organs of state. ${ }^{1}$ State being territorial in nature, the law is conceived as territorial. Therefore, the enforcement of law is undoubtedly territorial in the same way. The state power is exercised only within the territory of the state. The exercise of state power may extend to its public ships, aircraft, vessels and aircraft registered on the basis of objective territorial principle. ${ }^{2}$ The territoriality of law arises from the political division of the world. As a general rule no state allows other state, institute or person to exercise powers of government from outside. Hence, the enforcement of law is confined to the territorial boundaries of any particular state. Enforcement of law being physical affair its manifestation is taken place in physical space and understood as being territorial. The legal system of a state applies to all persons, things, acts and events of defined territory but not elsewhere. This is a generalized idea of states. Maybe it is a rough and imperfect generalization. It is also true that physical borders are not simply arbitrary creation. They sprung from historical necessity, cultural diversity, geographical proximity, religion, geopolitics, decolonization, globalization and international trends etc. Whatever factors lie behind the border set-up for demarcation of the state territory, the law made for territorial institution i.e. state is obviously of territorial nature.

Control over place, person, property, things and event is fundamental attribute of sovereignty and statehood. ${ }^{3}$ Law itself requires some mechanism for law enforcement. It depends on the ability to exercise physical control over, and to impose coercive sanctions on law-violators. The correspondence between physical boundaries and boundaries in "law space" also reflects a deeply rooted relationship between physical proximity and the effects of any particular behavior. We generally accept the notion that the persons, property and events within a geographically defined border are the causes of legislation. ${ }^{4}$ Physical boundaries are also appropriate for the delineation of "law space" in the physical world because they can give notice that the rules are changed when the boundaries are crossed. Proper boundaries indicate that different rules have to be obeyed, and physical boundaries are generally well-equipped to serve this over crossing border function. ${ }^{5}$

The law applicable to the cyberspace is quite different form territorialbased law because of the peculiarity of cyber world bearing virtual character of visual nature. It should be considered that the events or activities of cyber world causing legal consequences are not less than those of the real world. ${ }^{6}$ Accordingly a distinct set of laws and legal principles is desirable for the purpose of punishment or remedy. The 
financial losses suffered in cyber space by the individual or by corporate body or by governmental organs sometimes surpass traditional territorial-based damage. ${ }^{7}$ However, the legislation and the application of law regarding Internet or cyberspace are not independent of territorial practices. The territorial law supplies element for cyber legal issues in the USA. The cyber issues are being settled within existing legal and constitutional framework. The American courts whether federal or provincial are very much inclined to decide the Internet cases on the basis of territorial concept. It is noteworthy that in some cases the court declared their decisions relying on precedent of such period when the cyber concept was non-existent. So it will be unusually dynamic to think that trial of cyber offences could be devoid of traditional concept. As a lively organ of a hi-tech nation the US judiciary is handling the cases arising out of cyber activities. American practices show that it takes resort to the traditional territorial principles in cognizance, trial and judgment of Internet cases. So the aims of this study are:

a. to study the American cases as a representative type of hi-tech nation for searching the influence of traditional territorial concept upon the settlement of internet-cases;

b. to find out the influence of territorial tenets in taking cognizance and other jurisdictional issues, rationality and decisions;

c. to show the way for overcoming the overawe came out of cyber peculiarity on the basis of traditional notion.

\section{Transborder Scenario: American Concern}

Cyberspace $^{8}$ has no territorial boundaries, so the cost and speed of message transmission through the net is entirely independent of physical location. Messages can be transmitted from any physical location to any other location without degradation, decay or delay. Physical cues or barriers that keep certain geographically remote places and people separate from one another do not make any impediment in Internet. ${ }^{9}$ The Net enables transactions among people ignorant of the physical location of the other party. There is no connection between an Internet address and a physical location. Hence, control of activity in Cyberspace has very tenuous connections to authority of physical location. Primarily many governments responded to electronic communications crossing their territorial borders by trying to stop or regulate the transborder information flow. ${ }^{10}$ In particular, resistance to "Transborder Data Flow" (TDF) reflects the 
concerns of sovereign nations that the development and use of TDFs will undermine their "informational sovereignty," will negatively influence on the privacy of local citizens, ${ }^{11}$ and will upset private property interests in information. ${ }^{12}$ Even local governments in the United States have expressed concern about their loss of control over information and transactions flowing across their borders. ${ }^{13}$ But efforts to control the flow of electronic information across physical borders are likely to prove futile, at least in countries that hope to participate in global commerce. ${ }^{14}$ Individual electrons can easily, and without any realistic prospect of detection, "enter" any sovereign's territory. The volume of electronic communications crossing territorial boundaries is just too great in relation to the resources available to government authorities to permit meaningful control.

\section{Territorial Precedent Creates Grounds for Cyber Jurisdiction:}

Trademark violation, defamatory matters, commercial offences and monetary fraud etc are highly committed relating to Internet in the USA. The American courts in deciding these cases depend on the territorial and traditional norms and principles. It can be inferred from the judgment of Internet based cases in different courts of the USA whether federal or state (U.S) courts. In internet cases the judges of American courts are very much inclined to follow the traditional territorial-based legal principles. Due to the scarcity of law for numerous cyber offences the courts are to take resort to the previous interpretation applied in the territorial-based disputes.

In order to be subject to personal jurisdiction in a state (U.S) nondomicile, a person must be qualified under the realm of the state's (U.S) "long-arm" statute and the Due Process Clause of the Fourteenth Amendment. The U.S. Supreme Court set the constitutional standard for jurisdiction in International Shoe Co. v. Washington. ${ }^{15}$ Pursuant to the Due Process Clause, a non-resident defendant may not be sued in a forum in the absence of sufficient "minimum contacts" with the forum state (U.S) so that the initiation of suit conforms to traditional notions of fair play and substantial justice. ${ }^{16}$ Moreover, the non-resident's "conduct and connection with the forum state (U.S) must be such that he should have reasonable prediction to be hailed into court there."17 The courts may exercise discretion to decide what contacts are sufficient, in the light of "traditional notions of fair play and substantial justice." 18 
In general the Courts hold the view that contacts are sufficient to satisfy due process only if the non-resident "purposefully availed" himself of the benefits of being present in, or doing business in, the forum state (U.S). ${ }^{19}$ According to the Supreme Court in Asahi Metal Industry v. Superior Court, ${ }^{20}$ a connection sufficient for minimum contacts may take place by an action of the defendant purposefully directed towards the Forum State (U.S). Simply placement of a product into the flow of commerce not being followed by advertising or marketing is not an act of the "defendant purposefully directed" towards the Forum State (U.S). But advertising or marketing in the Forum State (U.S) may fulfill the deliberate requirement. There must be clear evidence that the defendant intended to serve the particular market. ${ }^{21}$ After exhaustion of the minimum contacts test the court will find out reasonableness to exercise jurisdiction. In determining reasonableness, a court must (1) weigh up the burden on the defendant to litigate in the forum state (U.S), (2) consider the interest of the forum state (U.S) in the matter, (3) ascertain the interest of the plaintiff in obtaining relief, (4) scrutinize the efficiency of the forum state (U.S) in dispute settlement, and (5) look over the interests of several states (U.S) in furthering certain fundamental social policies. ${ }^{22}$ After the satisfaction about minimum contact and reasonableness the U.S. courts of any particular state (U.S) will exercise jurisdiction over a person of another state (U.S) or country whose performance has rendered substantial effects in the forum state (U.S) and constituted sufficient contacts with the forum state (U.S) to satisfy due process. This jurisdictional test is sophisticated and extensive with regard to internet cases. The courts in every state (U.S) of the U.S. may be able to exercise jurisdiction over persons across the world, relying upon Internet contacts with the state (U.S). This has been popularized by American jurists as minimum electronic contacts. If minimum contacts exist, persons from other countries may be hailed into court in the United States just as persons from one state (U.S) may be hailed into another state (U.S). ${ }^{23}$

\subsection{Source of the Cyber Law Principles: Territorial Analysis of Uploading and Downloading}

The traditional territorial law supplies the ingredients of cyber laws. It will play vital role in emergence and development of the basic principles of cyber laws. The future Cyber- law- principles are nothing but the most modern version of territorial principles to cope with cyber necessity. The territorial precedent can establish the basis for the legal framework for cyber cases. Even these territorial precedents can 
contribute to the development of settlement process for cyber offence. The public interacts with cyberspace in two primary ways, e.g. (1) putting information into cyberspace or (2) taking information out of cyberspace. There are two distinct actors such as the uploader and the downloader, which can be familiarized with legislation for cyberspace. This theory of uploader and downloader acts like spies in the classic information drop. The uploader puts information into a location in cyberspace, and the downloader accesses to it at a later time. Some areas of the Internet are accessed by thousands of people from all over the world. In both civil and criminal law, most actions taken by uploaders and downloaders present no jurisdictional difficulties. A state can forbid, on its own territory, the uploading and downloading of material it considers harmful to its interests. A state can therefore forbid anyone from uploading a gambling site from its territory, and can forbid anyone within its territory from downloading, i.e. interacting, with a gambling site in cyberspace. In that sense, the traditional territorial law can provide rules for the cyberspace regarding jurisdiction or for other issues arising out of cyber connection. Two early American cases demonstrate how this theory would be adjustable. The Schooner Exchange ${ }^{24}$ held that a French war vessel was not subject to American law, although it was in an American port. Similarly, a web page can be ascribed to the nationality of its creator, and thus will not be subject to the law of wherever it happened to be downloaded. The Cutting Case ${ }^{25}$ provides an example of how an uploader should be viewed in a foreign jurisdiction that offended by material uploaded into cyberspace. Mr. Cutting published an article in Texas, which offended a Mexican citizen. When Mr. Cutting visited Mexico he was incarcerated on criminal libel charges. The United States Secretary of State instructed the U.S. ambassador in Mexico to inform the Mexican government that the "judicial tribunals of Mexico were not competent under the rules of international law to try a citizen of the United States for an offence committed and consummated in his own country, merely because the person offended happened to be a Mexican." ${ }^{26}$ A general inference can be drawn that uploading certain materials from any state is a crime like an offence "committed and consummated" in the state wherefrom the upload performs his job. But American practice is not uniform in all cases. The passive personal jurisdiction proposed by Mexico was rejected by the USA. It is remarkable that after more than one hundred years the American authority emphasized upon this principle of passive personal jurisdiction in the USA vs. Yunis ${ }^{27}$ to punish the offender for the crime committed against the passengers including some Americans 
by aircraft hijacking. In the Bhopal case the USA showed the same approach. ${ }^{28}$ However, it is evident that the territorial precedents can be placed in solving the legal problem arising out of Uploading and Downloading.

\subsection{Minimum Electronic Contact is also based on Territorial Concept}

The minimum Contact is a frequently reported principle in the context of personal jurisdiction. This theory has remarkably performed substantial ground works for establishing the concept of "Minimum Electronic Contact" ${ }^{\prime 29}$ ascribed to the internet-based interaction /communication. Jurisdiction over communications, transactions and other matters conveyed on the Internet raises new issues at the millennium. The concept of territorial boundary imposes restrictions on judicial power over persons outside the territorial border. ${ }^{30}$ According to the territorial principle a person outside a state must have "minimum contacts" with forum state to exercise judicial power over the foreign party. The Due Process Clause of the American Constitution entails physical presence or a sufficient quantity and quality of contact in the forum state (U.S) to assert personal jurisdiction. $^{31}$ The "minimum contacts" standard leads to the broadening of jurisdiction through long-arm statutes over out-of-state (U.S) persons. The access into the Internet can subject the users of this medium to jurisdiction all over the world. It is said 'the THERE is everywhere where there is Internet access. ${ }^{32}$ So the judges find difficulty in exercising jurisdiction in commerce and communications through Internet. It is notable that trademark and similar intellectual property have contributed largely to the development of Internet jurisdictional jurisprudence. In the huge number of cases, courts exercised personal jurisdiction over the persons outside the forum state (U.S) transmitting messages into it via the Internet. ${ }^{33}$

The fact of Inset Systems, Inc. v. Instruction Set, Inc., ${ }^{34}$ discloses that Inset Systems, Inc. ("Inset"), a Connecticut corporation, discovered that Instruction Set, Inc. ("ISI") a Massachusetts corporation had violated its trademark by using the domain address INSET.COM and the telephone number 1-800-US-INSET. ISI argued for want of personal jurisdiction. The court agreed and relied upon two territorial cases ${ }^{35}$ to establish that ISI's advertising over the Internet was solicitation of a sufficient repetitive nature to satisfy Connecticut's long-arm statute. ${ }^{36}$ Whatever be the decision of the case, for upholding electronic or internet minimum contact basis, the attempt of the courts 
moved toward the reliance of the minimum contact basis as followed in territorial disputes.

\subsubsection{Asahi Metal Test}

The case of Asahi Metal Industry v. Superior Court ${ }^{37}$ will provide the principles for cyber jurisdiction. In this case the Supreme Court of the USA analyzed two points regarding jurisdiction e.g., (1) whether the non-resident defendant deliberately availed himself of the laws of the forum state (U.S), and (2) whether exercising jurisdiction over that defendant would be fair and reasonable. This view ensures that nonresident defendants will not be subject to jurisdiction for just placing goods in the "stream of commerce." 38 This first point of analysis prevents courts from asserting jurisdiction only for the reason that a nonresident defendant knows about a possible connection with the forum. The court observes that the "substantial connection" between the defendant and the Forum State is indispensable for minimum contacts to establish an action of the defendant purposefully directed toward the Forum State. The placement of a product into the stream of commerce, without doing anything more, is not an act of the defendant purposefully directed toward the Forum State. Conduct of the parties that accomplishes the deliberate availment requirement includes advertising or marketing in the forum state. In general, if the minimum contacts prong of the due process analysis is satisfied, courts must still evaluate the reasonableness of exercising jurisdiction over the defendant. ${ }^{39}$

\subsection{Principle of Defamatory Targeting derives from Territorial Practice}

The principle of "targeting" is the core of Internet defamation cases. The concept predates the Internet. In Burger King Corp. $v$. Rudzewicz, ${ }^{40}$ a case decided before the beginning of Internet era the Supreme Court upheld long-arm jurisdiction because the foreign defendant purposely was "targeting" the residents of a foreign state. The same principle was applied in upholding long-arm jurisdiction in defamation cases. In Calder $v$. Jones, ${ }^{41}$ the court upheld personal jurisdiction in California over two Florida residents who wrote an article that defamed a California resident, even though neither of the Floridians had any physical contact with California. The Court accepted the reason that alleged wrongdoing intentionally was directed at a California resident. The same reasoning was applied in a defamation case of uploading and other defamatory activities in Internet. In EDIAS Software Int'l. v. Basis Int'l. Ltd., ${ }^{42}$ New Mexico Software Company placed libelous remarks about an Arizona 
distributor on its website and in e-mail to its customers in Europe. The "Arizona-target" sued in Arizona, and the court upheld jurisdiction over the New Mexico Company, even though the communications arose out of the forum state (U.S). The court took view that Arizona could assert jurisdiction because it was the place where the "target" of the communication "felt the economic impact" of the defamatory statement. ${ }^{43}$ In Blumenthal v. Drudge $e^{44}$ the court upheld on the same reasoning that the District of Columbia had personal jurisdiction. ${ }^{45}$

Other courts have sought same reason to uphold jurisdiction over the Internet. In Telco Comm. v. An Apple a Day ${ }^{46}$ the posting of a defamatory press release on an Internet site was sufficient to confer jurisdiction over an out-of-state (U.S) party. It is also notable that in some cases it was held that Internet defamation does not give rise to jurisdiction in the state where the plaintiffs reside or claim harmful effects. But in fact the origin of defamatory target can be traced back to the territorial notion.

\subsection{Cyber Offences Posses Spirit of Traditional Crimes}

The architectural structure of cyber territory is different from realworld-territory. But the activities/offences occurred in cyberspace has similar economic, social, cultural, civil or political effects like other territorial activities or traditional crime such as theft, fraud, misrepresentation, slander, libel, assault and battery etc. So the courts in America do not compromise about established norms to deal with the technological challenge so as to cuff evasive strategy of the cyber offenders using cyber peculiarity.

In US vs. Thomas, ${ }^{47}$ the Sixth Circuit upheld the conviction of a couple operating a pornographic bulletin board from their residence at Milpitas in California the defendants began to operate the Amateur Computer Bulletin Board System [AABBS] since Feb 1991. The AABBS contained approx 14,000 Graphic Interchange Format [GIF] files. The files could be accessed by members who possessed the password. Once the password was entered, the users were able to select, retrieve, or downloaded the GIF files to their own computers. The government got involved in AABBS' activities upon a complaint of a web surfer inflicted by the introductory screens during his exploration. In 1994, a U.S. Magistrate Judge for the Northern District of California issued a search warrant authorizing a search of the defendant's home. Accordingly their computer system was confiscated. The defendants were convicted in the U.S. District Court on federal 
obscenity charges. They appealed and the appellate court affirmed. There were two points for their appeal: (1) The federal obscenity statute did not apply to intangible objects like computer GIF files, and (2) Congress did not intend to regulate the type of transmissions in question because the federal obscenity statute did not expressly prohibit such conduct. The defendants contended that the GIF files were an intangible string of 0's and 1's, which only became viewable images after being decoded in the AABBS member's computer. The court disagreed and expressed observation that the fashion in which the images were transmitted did not affect their ability to be viewed or printed out by members in Tennessee.. The court ruled that the statute must be construed to affect the intent of Congress, which was to prevent the channels of inter-state (U.S) commerce from being used to disseminate any obscene matter.

In Miller v. California ${ }^{48}$ the court observed that obscenity was to be judged by contemporary community standards lied in the realization of average person. In many other subsequent cases the court is more drastic in receiving traditional notion. In cybersell Inc $v$.cybersell,Inc the court is pragmatic to state that erecting a website can be compared to publishing in a widely distributed general-interest magazine. ${ }^{49}$ In fine it can be said the court did not deviate from the conventional norms and values.

\section{Concluding Remark}

American courts follow the traditional territorial concept in deciding Internet cases. Trademark violation, defamatory cases, target, purposeful availment and jurisdiction are the territorial notions. These are now being used frequently in internet- cases. It is a substantial matter that the technicality of internet exposes some complications in the legislation, statutory interpretation, enforcement of law, trial procedure and dispute settlement. All sovereign States are afraid that they will not be able to control the internet- activities or to regulate cyberspace or to settle cyber dispute due to the non-existence of a sound set of rules. But it is a matter of happiness for they can take resort to the American practice revealing that traditional territorial legal principles can be used potentially to resolve the cyber conflicts. Finally cyber peculiarity has not proved as a problematic for the courts of law because the judges, lawyers and all others will not have to go outside the purview of traditional territorial notion. 


\section{Notes and References}

1 To avoid the confusion between the state of federal sense and the state of sovereign status, they are termed as state (U.S) and the state respectively (where necessary).

2 Fitzerald, P. j (1999) Salmond Salmond on law,12th edition .p75

3 Johnson, David R. and David Post, (May 1996), Law and Borders--The Rise of Law in Cyberspace, 48 Stanford L.Rev. pp1357-67.

4 Declaration on Principles of International Law Concerning Friendly Relations and Cooperation Among States in Accordance with the Charter of the United a Nations, G.A. Res. 2625, 35th Sess. (1970); Declaration of the Inadmissibility of Intervention into the Domestic Affairs of States, (1965) G.A. Res. 2131, 30th Sess.

5 Henry, H. Perritt Jr (Jan. 25, 1996). (Apr.1995), Self-governing Electronic Communities pp 36-49, 59-60.

6 Biegel, Stewart, The Emerging and Specialized Law of the Digital Revolution, Los Angeles Daily Journal, at 1. http:// www.gse.ucla.edu /iclp/jan96.html.

7 Mark, Kravitz, (Apr. 21, 1997) Sum \& Substance: A Virtual Presence, The Connecticut Law Tribune, at p.1. http:// www.courttv.com / news / 422f.html.

8 Internet is an interconnected system of networks that connects computers around the world via the TCP/IP protocol and provides a non-physical working place for the users. This place is known as cyberspace. The term "cyberspace" is sometimes treated as a synonym for the Internet, but is really a broader concept. The term cyberspace emphasizes that it can be treated as a place. The United States Supreme Court's first opinion about the Internet contains language that can be determined as acceptance of the legal metaphor of cyberspace as a place outside national boundaries. The expression of the court was significantly distinctive when it states that a unique medium consisting of certain tools located in no particular geographical location but available to anyone, anywhere in the world, with access to the internet that is known to its users as 'cyberspace'. See also C, Darrel. Menthe, (1998) Jurisdiction in Cyberspace: A Theory of International Spaces, 4 Mich. Telecomm. Tech. L. Rev. p. 69 available at http://www.mttlr.org/volfour/menthe.pdf

Biegel, Stewart. (Jan. 25, 1996) The Emerging and Specialized Law of the Digital Revolution, Los Angeles Daily Journal, at 1.<http://www.gse.ucla.edu/iclp/jan96.html $>$ and Wilske, Stephan \& Teresa Schiller, (1970), International Jurisdiction in Cyberspace: Which States May Regulate the Internet? 50 Fed. Comm. 1. J. 117, 126, citing Barcelona Traction,(Feb. 5) Light and Power Co. (Belg. v. Spain), I.C.J. 3, pp.17-53 .

9 Katsh, M. Ethan, (1989), The Electronic Media and the Transformation of Law 92-94 M. Ethan Katsh, Law in a Digital World 57-59, 218 (1995). 
10 Auerbach, Jon (Feb.1, 1996), Fences in Cyberspace; Governments Move to Limit Free Flow of the Internet, Boston Globe, at 1(surveying "digital Balkanization" of the Internet through government censorship and filtration).

11 Miller, Anthony Paul, (1986), Teleinformatics, Transborder Data Flows and the Emerging Struggle for Information: An Introduction to the Arrival of the New Information Age, 20 Colum. J. L. \& Soc. Probs. 89, 107-08, 127-32 (exploring the willingness of some national governments to forego the benefits of unregulated TDF's so as to protect their political, social, and cultural interests).

12 Ibid

13 Spears, Gregory, (Feb. 1995), Cops and Robbers on the Net, Kiplinger's Pers. Fin. Mag., at 56 (surveying responses to online investment scams).

14 Wriston, Walter B., (1992), The Twilight of Sovereignty (examining the challenges to sovereignty posed by the information revolution).

15326 U.S. 310 (1945).

16 Int'l Shoe Co. v. Washington, 326 U.S. 310 at 316.

17 World-Wide Volkswagen v. Woodson, 444 U.S. 286, 297 (1980).

18 World-Wide Volkswagen v. Woodson, 444 U.S. 286, 297 (1980).

19 See, e.g. Burger King v. Rudziewicz, 471 U.S. 462, 475 (1985).

20480 U.S. 102 (1987).

21 Id. From a policy standpoint, this might prevent prosecutions in cases where the provider did not know the location of the user, but would facilitate and encourage false identification of user location to circumvent laws. For example, a person in Minnesota (with strict laws regarding Internet gambling) could use a dial-up connection to an Internet Service provider in Canada before gambling at a site hosted by a server in Liechtenstein. The Liechtenstein site operator could track the user back to Canada without knowing that the user was actually breaking the law. Operators of gambling sites could encourage users to uses such misleading dial-up connections.

22 Id. at 113. (eight of the nine Asahi justices agreed that, regardless of whether there are sufficient minimum contacts, exercising jurisdiction over the defendant in Asahi would be unreasonable).

23 This is evident from the Restatement (Third) of the Foreign Relations Law of the U.S. § 402-03 (1987), which states that a nation may make laws with regard to: "conduct outside its territory that has or is intended to have substantial effect within its territory," subject to a reasonableness requirement. The Restatement (Third) of the Foreign Relations Law of the U.S. is intended to reflect the international law consensus of all nations. See Stephan Wilske \& Teresa Schiller, International jurisdiction in cyberspace: Which States May Regulate the Internet? 50 Fed. Comm. L.J. 117, 126.

24 The Schooner Exchange v. McFaddon, 11 U.S. (7 Cranch) 116 (1812). 
25 Letter, Secretary of State to United States Ambassador to Mexico. Department of State, Washington, November 1, 1887 (reprinted in part in, Joseph Sweeney, et al., The International Legal System 90-93) (emphasis added). See also Rahman, Mizanur (2003) International Law in a changing world(Bengali) Dhaka,Pallal prakashani p-64.

26 Id

27 Available at http:// www.terrorismcentral.com /Library /Teasers / YnisAppealT.html.

28 Govt. of India vs UC.C. (Bhopal) Corp, 1987 cited in Rahman Mizanur. 2003, Internatioal Law In A Changing World (Dhaka Palal Prakashani) p91

29 Ignoring all the legal technicalities, for better understanding of minimum electronic contact a hypothetical example can be derived from the minimum contact basis of Asahi to analogize between the cyber or electronic minimum contact and territorial minimum contact ---a website which offers special prices for New York residents. This site would be taking advantage of New York residents for financial gain and such conduct would constitute deliberate availment. The site owner, therefore, could be hailed into court for a lawsuit initiated by a New York resident which arose from the special offer.

30 Harris v. Balk, 198 U.S. 215 (1905).

31 Aftenase v. Economy Baler Co., 343 F.2d 187 (8th Cir. 1965); Hardrives Inc. v. City of LaCrosse, 240 N.W.2d 814 (Minn. 1976); Dent Air, Inc., v. Beach Mountain Air Serv. Inc., 332 N.W.2d 904 (Minn. 1983).

32 Digital Equipment Co. v. Alta Vista Technology, Inc., 960 F.Supp. 456, 462 (D. Mass. 1997).

33 Panavision Int'l. v. Toeppen, 141 F.3d 1316 (9th Cir. 1998); CompuServe, Inc. v. Patterson, 89 F.3d 1257 (6th Cir. 1996); Telco v. An Apple aA Day, Inc., 977 F.Supp. 404 (E.D. Va. 1987); Martiz, Inc. v. Cyberhold, Inc., 947 F.Supp. 1320 (E.D. Mo. 1996); Hall v. La Ronde, 66 Cal.Rptr.2d 399 (Cal Ct. App. 1997); Zippo Mfg. Co. v. Zippo Dot Com, Inc., 952 F.Supp. 1119 (W.D. Pa. 1997); Inset Systems, Inc. v. Instruction Set Inc., 937 F.Supp. 161 (D. Conn. 1996).

34937 F.Supp. 161 (D.Conn. 1996).

35 McFaddin v. National Executive Search, Inc.,354 F.Supp. 1166, 1169 (D.Conn. 1973), Whelen Eng'g Co. v. Tomar Elecs., 672 F.Supp. 659 (D.Conn. 1987).

36 Moreover, in order to meet Due Process requirements the court had to satisfy two tests. First, that a non-resident corporate defendant have minimum contacts with the forum state (U.S) such that it would reasonably anticipate being hailed into court.36 Second, that maintenance of the suit in the forum state (U.S) would not offend traditional notions of fair play and substantial justice. 36ISI claimed that minimum contacts was lacking. ISI said it did not conduct business in Connecticut on a regular basis, it did not maintain an 
office in the state (U.S), nor did it have a sales force or employees in the State (U.S). Accordingly, ISI argued, the court should find that the minimum contacts test was not satisfied.

37480 U.S. 102 (1987).

38 Black's Law Dictionary defines stream of commerce as the "term used to describe goods which remain in interstate commerce though held within a state for a short period of time".

39 The Asahi court evaluated the reasonableness of asserting jurisdiction by considering defendant's burden, the forum state's interests, interest of the plaintiff, competence of the forum, and inter-related interests of the several states (U.S) regarding fundamental issues almost of social nature. The Supreme Court's decision in Asahi Metal Industry Co. v. Superior Court rendered some confusion regarding clear definition of minimum contacts. The plurality opinion of Justice O'Connor has become acceptable criteria to be applied in cyber disputes. The opinion provides that the placement of a product into the stream of commerce, alone, is not an act of the defendant purposefully directed toward the Forum State. On the other hand, the dissent in Asahi argued that the stream of commerce was a predictable flow of products. The dissent's view posits that one who places a product into the stream of commerce with the knowledge that the final product will be sold in a particular forum should reasonably anticipate being hailed into court in that forum.

40471 U.S. 462 (1985)

41465 U.S. 783 (1994),

42947 F.Supp. 413 (D. Ariz. 1996),

43947 F.Supp. at 420.

44992 F.Supp. 44 (D.D.C. 1998)

45992 F.Supp. at 57.

46977 F.Supp. 404 (E.D. Va., 1997),

4774 F. 3d 701 [ 6 th. Civ , 1996 ],

48 The case turned on the fact that even though the GIF files never actually left Northern California and were arguably not obscene under Northern California, Bay Area standards, they were obscene by the standards of Memphis, Tennessee. In affirming the lower court's judgment those defendants were violating federal obscenity laws, the Court applied the community standards of the geographic area where the materials were sent. 413 U.S. 15, 93 S.Ct. 2607, 37 L.Ed.2d 419 (1973)

49 Cybersell, Inc. v. Cybersell, Inc., 130 F.3d 414, 420 (9th Cir. 1997), citing Calder v. Jones, 465 U.S. 783 (1983) (publishing case). 